Jelena Cvijović

Milica Kostić-Stanković ${ }^{2}$

Marija Reljić ${ }^{3}$
JEL: P23, M12, G24

DOI: 10.5937/industrija45-15975

UDC: 005.346:336.717

Scientific Review

\title{
Customer relationship management in banking industry: Modern approach ${ }^{4}$
}

Article history:

Received: 10 July 2017

Sent for revision: 28 July 2017

Received in revised form: 24 August 2017

Accepted:28 August 2017

Available online: 10 October 2017

\begin{abstract}
Due to fierce competition in the banking sector, where the competitive struggle to win larger market share and attract the largest possible number of customers is constantly being led, and taking into account poorly differentiated offer of banks, adequate customer relationship management is a fundamental tool for achieving better business results. In this context, the subject of the paper is the identification of the characteristics of the modern approach to customer relationship management and factors that influence its successful implementation, in order to achieve long-term and mutually beneficial relations between banks and banking products and services users.
\end{abstract}

Keywords: customer relationship management, banking industry, segmentation, customer trust, customer satisfaction.

\section{Upravljanje odnosima s korisnicima u bankarstvu: Savremeni pristup}

Apstrakt: Usled oštre konkurencije u bankarskom sektoru, gde se kontinuirano vodi konkurentsko nadmetanje za osvajanje većeg dela tržišta, odnosno privlačenje što većeg broja korisnika, a uzevši u obzir slabo diferenciranu ponudu banaka, adekvatno upravljanje odnosima sa korisnicima predstavlja osnovno sredstvo za postizanje boljih poslovnih rezultata. U tom kontekstu, predmet istraživanja u radu odnosi se na utvrđivanje karakteristika

\footnotetext{
${ }^{1}$ Economics Institute, Serbia, jelena.cvijovic@ecinst.org.rs

2 University of Belgrade, Faculty of Organizational Sciences

${ }^{3}$ Economics Institute, Serbia

4 This paper is a part of research project No. 179001 financed by the Ministry of Education, Science and Technological Development of the Republic of Serbia
} 
Cvijović J. et al.: Customer relationship management in banking industry: Modern...

savremenog pristupa upravljanju odnosima s korisnicima i na faktore koji utiču na uspešnost ovog procesa, u svrhu ostvarenja dugoročnih i obostrano korisnih odnosa banaka i korisnika bankarskih proizvoda i usluga.

Ključne reči: upravljanje odnosima s korisnicima, bankarski sektor, segmentacija, poverenje korisnika, zadovoljstvo korisnika

\section{Introduction}

Contemporary financial service industry has become highly dynamic and turbulent, with many changes in form of new regulations, changed consumer behavior, increased usage of information and communication technology and intense competition (Lymperopoulos et al., 2013; Heinonen, 2014). Banks have to invest great eforts to create added value and one way to do that is to generate and support the development of long-term customer relationships that provide greater value than the value provided by the banking product itself. Building of any added value is hard to achieve nowadays since competitors' activities, which are often very similar, erode added value of any business (Zineldin, 2005).

Even though banking industry has faced significant changes in different business segments during the last two decades, such as: distribution changes (with greater usage of ATMs, PCs, Internet, mobile banking), reduction of transaction costs, increased speed of service substantially, managing of supplier-customer relationships is still one of the crucial issues in banking industry (Ndubisi, et al., 2007). Besides such changes on the providers' side, important changes appeared also on the customers' side. Customers have become more demanding, empowered to perform some activities that were previously handled solely by banks, more knowledgeable, sophisticated, aware of available alternatives, independent, in a position to negotiate with many different service providers and similar (Heinonen, 2014). Under the influence of such changes in customer behavior and their needs, and with the goal to gain and maintain market competitiveness, banks invest a lot of financial, technological and human resources in customer relationship management (CRM) (Jugovic, et al., 2015). Relationships must be such that both banking service providers and customers benefit from it on a long turm (Dimitriadis, 2011). As a result of such relationships, productivity and quality of banking services is rising based on the progress of relationship between banks and customers (Brige, 2006).

Today, with the wide usage of electronic communication technologies, customer relationship management has undergone significant changes and it reppresents a system which includes all aspects of communication and interaction with customers and, in other words, it determines how to work with 
Cvijović J. et al.: Customer relationship management in banking industry: Modern...

customers, solve their problems, persuade them to purchase banking products and services, generate a feeling of loyalty and maintain financial interactions with customers (Rezghi, et al., 2014).

\section{Literature review}

The issue of customer relationship management has become the subject of research of many scolars and practitioners. Dimitriadis (2011) found out that customers are able to clearly identify benefits linked to potential or existing relationship and separate them from the offered products and services. The perceived benefits were put into the following categories: trust (based on the customers' opinion that relationships generate a perception of security); customization and special treatment (customers' expectations are focussed in the way services are delivered and adjusted to specific situations); social bonds (customers think that investments in establishing and maintaining of relationships are based on their personal importance for banks) and convenience/responsiveness (doing business with already known service provider makes such activities more easier).

Zineldin (2005) pointed out that banks must always keep in mind that they are not only offering and selling their products and services, but, they are also offering their organization reputation in every relationship established with customers. That is why banking service providers have to make aditional efforts to incorporate special values into their offer and relationships they establish with customers. Values such as: friendliness, politeness, helpfulness, transaction accuracy and carefulness, efficiency in correcting mistakes, speed of services and decision process were found to be more important to customrs than price of services (Zineldin, 2005).

Besides that, aushors Shakil, Shahid and Ehtisham-Ul-Mujeeb (2012) pointed out the importance of adoption and implementation of electronic banking, as a manner of reduction of operational and transactional costs and increasing of customer satisfaction. But, the prequaisite for this is to provide enough support to customers to adopt and use new technologies. On the other hand, some authors among which (Herington \& Weaven, 2007) found out that online service has no significant impact on customer satisfaction and development of solid relationships with customers since online bank services are today considered to be everyday practice and, therefore, are not the part of special customers' expectations when it comes to banking services.

The main finding of the study of Lundahl, Vegholm and Silver (2009) is based on distinguishing between technical and functional dimensions of customer satisfaction as a result of established relationships. The technical dimension is 
Cvijović J. et al.: Customer relationship management in banking industry: Modern...

based on what is delivered, while the functional dimension is based on social interaction between subjects in the relationship.

Effective customer relationship management is surely of a strategic importance, but relationships with customers are operationally managed by personal bankers who operate as advisers, responsible for managing relationships with customers on a daily bases, establishing of a two-way communication with customers and providing customized information and advices on various issues that are bank-related. Advising process usually occurs in direct meetings, since it is the best channel of communication when personal bankers' commitment to relationships with each of customers is manifested in a best way (Strandberg, et al., 2012).

In the research of Wisskirchen et al. (2006), obtained results showed that banks perceived six crucial imperatives for attracting new customers and strengthening relationships with existing ones: appealing marketing messages, precise targeting of prospects, managing the experience, providing extra services along with basic ones, being different, allowing customers lead conversations and making the foundation for customer- led growth.

There are many elements of customer-perceived value, including: faster service delivery, greater revenue, lower costs, availability of information, security of personal and transactional data, privacy, service quality and perceived usefulness (Shakil, et al., 2012).

In literature is often pointed out to the connection and inter-dependance of customer relationship management and relationship marketing. Relationship marketing enavbles banks to detect and better understand customers' needs and consequently offer and deliver superior value that will make customers satisfied and make them loyal in the long-term. Taking into account that the cost of serving one loyal customer appeared to be less than the cost of attracting and serving one new customer, it is obvious why it is important to invest in relationship marketing instead of traditional marketing and advertising options (Ndubisi, et al., 2007). These authors also defined following factors that have an impact on the outcomes of relational efforts and relationship quality: competence, communication, commitment, and conflict handling (Ndubisi, et al., 2007). Mishra and Vaithianathan (2015) also supported the fact that "it costs less to retain a customer than acquire a new one" and, therefore, underlined the philosophy of importance of enhancing customer life-time value and generate customer loyalty instead of implementing traditional, short-term transaction-oriented marketing activities.

As stated by Brige (2006), one of the outcomes of effective and quality relationships is that both parties that are involved will reduce the possibilities of mistakes and problems, unnecessary costs and other negative impacts on 
Cvijović J. et al.: Customer relationship management in banking industry: Modern...

service quality which will further deepen the connection between banking institution and customers.

Banks today have recognized customers as their most important partner in business conduction and perceive customer relationship management as profitable and benefitioal (Plakoyiannaki, 2005). The customer relationship systems must be supported by other bank's main activities especially in the fields of marketing, sales, and customer information services and analytics (Ling \& Yen, 2001).

Banks need to develop a coherent CRM system in order to manage to effectively use the existing information and sources (Ekhlasi \& Al-Badawi, 2007). One of the most comprehensive definitions of contemporary customer relationship management is given by Rezghi, et al. (2014) and it said that "is a customer-focused business strategy that dynamically integrates sales, marketing, and customer care service in order to create and add value for the company and its customers. This process includes perpetual recognition, attraction, development, and maintaining successful customer relationship for increasing profitability due to repeating the purchase and word of mouth advertisements will directly affect a company's maintenance and profitability".

The research of Dahlstrom et al. (2014) showed that trust is an element of a crucial importance in banking industry since establishment of relationships between customers and banks appeared to be a double-sided problem, since both parties can appear differently depending on the level of trust they have in other party.

Heinonen (2014) pointed out that it is wrong to observe relationships mainly from the one side - either from the provider perspective (considering what providers are doing to make and maintain relationships with customers) or customer perspective (what customers are doing on their side). Instead, between these two extremes is the dyad, or the perspective on customer relationships which "focusses on the dualistic interaction between the customer and provider, and how the relationship may create value for both actors". As noted by Tang and Ai (2013), customer relationship management also can contribute to the reduction of many negative notions and reduce the possibilities of suspicious transactions, false reporting rates and many other malpractice.

\subsection{Customer segmentation as a basis for CRM concept application}

It is widely recognized that banks which established strongest relationships with customers will have the best chance to retain them in along term and the perquisite for that is to provide them with added value customized for their 
Cvijović J. et al.: Customer relationship management in banking industry: Modern...

needs. Customers' needs could be met with greater understanding of customer demographics and behavioural patterns (Estrella-Ramón, 2017). Banks, therefore, should invest in more thorough penetration and analytics of the existing customer database. A comprehensive customer database will allow a company to understand better customer's needs and provide them with proper services. The data about customer's needs and behaviour will enable banks to identify their key and most profitable customers, develop relations with potential customers and precisely calculate the revenue that is generated by individual customers and estimate opportunities for future business activities towards those custiomers (Zineldin, 2005). Therefore, in CRM context, the database is used mainly as a resource for achieving of benefit by leveraging customers' behavioural patterns (Cvijovic, et al., 2014). In order to effectively collect all necessary customer data, it is necessary to first create such internal organizational environment where everyone must be committed to collection of all available customer data, respecting the criteria of credibility and valuability for analytics and decision-making (Brige, 2006).

Contemporary views on CRM has "driven a re-evaluation of the role of customer data within the CRM framework" (Saarijärvi, et al., 2013). However, this approach of collecting and using customer data is nowadays criticized as being "a heavily firm-oriented construct" since customer data were used for a long time just to to serve banks' purposes. From the establishment of the CRM concept, supported by communication and informational technology, banks used available customer data in order to acquire new customers, retain current ones and deepen relationships with customers. Customer data served (and still do) as a tool for developing customized communications and cross-selling. Despite the constant development of CRM as a theoretical and practical concept, the role of customer data during its evolution remained somehow limited. However, contemporary views have challenged such traditional usage of customer data, "by shifting attention towards sharing data with customers rather than using it only for firm purposes" (Thaler, 2011).

Besides the customer data usage, it is still necessary that banks perform the segmentation of their customer database and construct different groups of customers based on the used criteria. Contemporary models of segmentation are mainly value-based which supports banks to facilitate customer management process. For example, (Ekinci, et al., 2014) recommended measuring potential value of current customers instead of current value and performing segmentation in accordance to that criteria. Additionaly, EstrellaRamón et al. (2017) proposed a customer lifetime value (CLV) model for classifying individual customers into groups and developing customized products for each of them. Application of CLV criteria in segmentation resuls in better customer related decisions due to application of more customer centric approach, focusing on most promising customers and more efficient budget allocation (Agaliotis and Hadzic, 2015). 
Cvijović J. et al.: Customer relationship management in banking industry: Modern...

There are many possible typologies of groups of customers in databases, and one of them is the following one (Dimitriadis, 2011):

- "Partners" - the oldest and the most relational customers that have the closest and relationship with the bank. They cooperate with the bank the highest number of years, have widest product portfolio and hifhest frequency of visiting the bank. This group is made of loyal customers that have many benefits from existing relationships with the bank and invested a lot of time and effort in such relationship.

- "Indifferent" - the youngest customers that are less relational prone, with the smallest product portfolio and shortest period of cooperation with the bank. Their banking experience is very low and limited to necessary transactions, without considering the establishment of relationshipa with the bank as significant and benfitial and, due to that, they are not willing to accept any costs relating to that.

- "Pragmatic" - middle - aged and relationship prone customers, who are not very frequent branch visitors and who do business with the bank for a few years. They have the need for establishment of close relationships with their bank, but, at the same time, thay are price sensitive. On the other hand, since they are experienced bank customers, they are able to understand what is necessary such relationships to be established, so they consider necesary time and effort for learning bank's procedures as a minimal effort which they are willing to make.

- "Hard" - older customers with lower frequency on visiting bank premices and significantly lower relational proneness. They are very demanding in terms of relationships, but they are unwilling to accept any costs and consequently they are the most difficult group of customers for banks.

\subsection{Factors that influence the development of long-term relations between banks and customers}

From the organizational aspect, successful CRM system adoption is determined by three fundamental and three means objectives. The three fundamental objectives are: maximization of CRM organizational culture; ensuring of an effective relationship with CRM providers; and minimization of CRM adoptation risks, while the three means objectives are: maximization of CRM usage, maximization of relational marketing capabilities and maximization of CRM orientation (Pedron, et al., 2016). From the customers' aspect, development of effective and long-term relationships with banks is affected by many factors, such as: trust in bank and its services, existing loyalty and satisfaction, percepcion of efficiency of communication channels, 
Cvijović J. et al.: Customer relationship management in banking industry: Modern...

existing sutomer knowledge of banks' products and services (especially in case of Internet and mobile banking etc.)

The importance of trust as a basic factor for the development of long-term customer and bank relationships is often highlighted in research. These realtionships are highly influenced by the "ability of bankers to understand and meet the specific needs" of customers, which, in return affects the overall customers' perceptions and attitudes towards banks (Vegholm, 2011). The role of trust is often observed two-fold, as a trust between consumers and the bank and interpersonal trust (e.g. trust of users to employees in banks), which mainly depend on competence of service providers and trust in their honesty and non-rebellious intentions.

In addition to trust, customers' satisfaction is also significantly covered in literature as main predictor of the possibility to develop long-term relationships between organizations and customers (Komazec et al., 2015). Ofori et al. (2017) found out that information quality, service quality, privacy and security concerns significantly predict both customers' trust and satisfaction, while structural assurance and situational normality significantly affect trust. In the context of Internet banking, trust is often stated to be the most important factor for greater adoption of online banking services, and it develops on the basis of consumer familiarity with internet banking, perceived structural assurance, perceived website quality, bank reputation and relative advantage (Kaabachi, et al., 2017). Furthermore, when observing trust in mobile banking, Arcand et al. (2017) found out that mobile banking service quality dimensions have an impact on trust and satisfaction. While trust is more associated with utilitarian factors (security/privacy, practicity), they noted that satisfaction is associated with more hedonic factors (like enjoyment and sociality).

Developed relationships with customers are found to be in positive association with customer loyalty which is expressed as "intentions to continue their relationship with and cross-buy other products from their bank" (Hoffmann \& Birnbrich, 2012). Greater customer satisfaction, loyalty and opportunities for cross-selling related and unrelated products of banks to their customers are to a large axtent affected by following five dimensions of effective customer relationship management: organizational commitment, customer experience, process-driven approach, reliability and technologyorientation (Padmavathy, et al., 2012). The loyalty has become important issue due to rising customer switching, therefore, banks make attempts to maintain a loyal customer base, in order to hold market position and be profitable (Lymperopoulos et al., 2013).

When it comes to the determinants of the development of long-term relationships, the efficiency of providing services is often emphasized as one 
Cvijović J. et al.: Customer relationship management in banking industry: Modern...

of the key ones. Efficiency is based on simplicity and functionality, which are highly valued, especially in the case of basic day-to-day tasks, speed, ease and process automation. Also, it was shown that the development of relationships with customers is greately influenced by the possibility to decrease the costs of interacting with customers, while, simultaneously, maintaining and even increasing customer retention and revenues related to their transctions (Saarijärvi, et al., 2013). Research results showed that customers' "intentions to switch banks" are mainly affected by their "price satisfaction". (Lymperopoulos et al.,2013). Paul, Mittal and Srivastav (2016) indicated that consumers' satisfaction is associated with a large number of factors that can contribute to it. It was found that "knowledge of products, response to need, solving questions, fast service, quick connection to the right person, and efforts to reduce queuing time" make the positive impact on the overall satisfaction, while "assistance to the customer, appearance, and follow up" influence the satisfaction negatively.

Considering the greater rate of usage of electronic banking, achievement of satisfaction of customers, as the outcome of their experience with online products is gathering the attention of authors (Liébana-Cabanillas, et al., 2013). The satisfaction of customers with online banking, is greately influenced by factors such as security, available infrastructure, regulatory norms, etc. (Saxena \& Al-Tamimi, 2017). Today, users are mostly familiar with the use of online banking as their daily routines and consider it the main link with their bank. Their attitudes to online services, as well as the trend of "self-service" in banking are generally positive (Kaushik \& Rahman, 2015).

In the context of the future of online banking, video calls and mobile banking are positively evaluated by users. Stone et al. (2017) noted "that digitalization, cloud computing and new information-based platforms are beginning to change how customer information is being managed, creating new opportunities for improving marketing, customer relationship management and business strategy" in online environment. Brun, Durif and Ricard (2014) pointed out the similarities and differences between relationships of banks and customers in traditional and internet context. When it comes to similarities, it was found that development of relationships is based on achieved customer satisfaction and bank while the simplicity and ease of the customer's web experience represent factors connected with e-banking. However, customers may be concerned about the alienation and impersonal relationship with the bank. Customers often express concern that, compared to traditional channels, it is much more difficult to get help in self-service channels, and thus resolving the problem takes longer period of time. For this reason, it is not considered justified to automatically assume that users want to give priority to online banking, because this trend by one segment of consumers is perceived as such that, the more transactions you can spend on 
Cvijović J. et al.: Customer relationship management in banking industry: Modern...

your own, fewer personal services will be offered to them (Adapa \& Roy, 2017). Among the potential negative phenomena in the development of longterm relationships, the literature mentions the incompatibility of the online banking system with the user's device, frequent inaccessibility or technical problems or poor usability. Generally speaking, there is generally a positive attitude towards the trend of "self-service" in banking, which is especially appreciated by younger customers (Lewis, et al., 2010). However, in the case of older users, there is still some doubt as to the pressure that more or more solely to resort to self-service.

When it comes to mobile customer relationship management (mobile CRM), empirical findings indicated perceived utility value to be the most important factor for mobile CRM services, followed by: ease of use, context, compatibility, cost, risk and personal innovativeness. On the contrary, negative attitude towards technology represent a restraining factor (Sangle \& Awasthi,2011). Sampaio, Ladeira and Santini (2017) emphasized that the benefits related to the usage of mobile banking are positively associated with customer satisfaction, which leads to the development of: trust, loyalty and positive word-of-mouth. In the context of mobile banking, better CRM strategies are definitely dependent on the adoption of mobile channel by greater number of customers. Therefore, perceptions, attitudes and intentions of mobile users are important detreminants of relationships development (Chawla \& Joshi, 2017). Research findings indicate that the greater adoption is crucialy influenced by: perspective of benefits, perceptions value, perceived usefulness and context, while also being significately influenced by perceived security assurance, perceived trust, perceived cost and perceived risk on perceived value and perceived usefulness (Awasthi \& Sangle, 2013).

Bhat and Darzi (2016) provided empirical evidence that the customer knowledge is the CRM dimension that has the most positive effect on the development of customer loyalty and competitive advantage of the bank. The customers' knowledge as the root for greater adoption of digital banking and development of digital CRM was noted by Larsson and Viitaoja (2017).

The importance of various communication channels in customer relationship management in banking market was investigated by certain number of authors. For example, Amoako et al. (2017), emphasized the importance of advertising communication in this context, as it was found to positively influence bank preference and customer loyalty in mobile banking. KosticStankovic (2013) emphasised the importance of integrated marketing communications in customer relationship management, especially when it comes to the influence on the behavior of heterogeneous customer segments. Furthermore, it was shown that banks can maintain and improve relationships with customers by improving the efficiency of communication channels, from 
Cvijović J. et al.: Customer relationship management in banking industry: Modern...

the aspect of sending important and accurate information, as well as from the aspect obtaining valuable information from the customers' side (Valmohammadi \& Beladpas, 2014; Tran \& Corner, 2016).

Despite the increasing role of self-service in banking, personal contact and efficient contact services are still considered to be extremely important factors in the development of long-term relationships with customers. The role of contact centres in banking industry, as a means for establishment of better relationships with customers is pointed out by Stefanov and Kostic-Stankovic (2014) and Stefanov, et al. (2015). Contact centers often represent "main touch points of customers in an organization" and are, therefore, important factors of customer satisfaction. Due to the higher usage of information and communication technologies, contact centres evolved in operational terms and have become strategic element of customer relationship management (Saberi, et al., 2017).

In relation to meeting customers' needs, additional services offered by banks are often considered necessary for the development of long-term relationships with customers. However, this context, it is crucial to explore customer opinions on new services that banks can offer in the future since customers may be skeptical of non-traditional services, and two main reasons for this are the lack of trust and general resistance to change. Although some additional services, such as the sale of insurance, are often considered favorable by consumers, there is certain concern over the fact that banks are tending to lose their focus with the inclusion of unrelated services (Lee \& Liu, 2017). So, inclusion of additional services, as means of establishing more solid relationships with customers, needs to be carefully analysed and reconsidered by banks, so those services meet the needs of different customer segments.

\section{Conclusion}

The changes in financial market and customer preferences and behavior, as well as greater application of modern technologies demand an application of CRM in banking industry. CRM enables segmentation of customers in accordance with different criteria, which enables customization of banking products and services and continous innovation of product portfolio. CRM provides the possibility to create active, "friendly" relationship with customers, which certainly contributes to their loyalty to banks and the provision of permanent and secure revenues in the long turm. Today, when needs and expectations of customers are rapidly changing and becoming more sophisticated, the real business success can be achieved only in case banks 
Cvijović J. et al.: Customer relationship management in banking industry: Modern...

manage to adequately establish and maintain relationships with their customer. Therefore, CRM in a contemporary context represents the crucial factor for the achievement of the overall business success and survival in the market, when it comes to traditional banking, but especially in the context of Internet and mobile banking.

\section{References}

Adapa, S., \& Roy, S.K. (2017). Consumers' Post-Adoption Behaviour towards Internet Banking: Empirical evidence from Australia. Behaviour \& Information Technology, 36(9), 970-983.

Agaliotis, K., \& Hadzic, M. (2015). Can retail banking clients' attrition be managed? Industrija, 3(43), 107-122.

Amoako, G.K., Anabila, P., Effah, E.A., \& Kumi, D.K. (2017). Mediation role of brand preference on bank advertising and customer loyalty: A developing country perspective. International Journal of Bank Marketing, 35(6), 983-996.

Arcand, M., Promtep, S., Brun, I., \& Rajaobelina, L. (2017). Mobile banking service quality and customer relationships. International Journal of Bank Marketing, 35(7), 1068-1089.

Awasthi, P., \& Sangle, P.S. (2013). The importance of value and context for mobile CRM services in banking. Business Process Management Journal, 19(6), 864891.

Bhat, S.A., \& Darzi, M.A. (2016). Customer relationship management: An approach to competitive advantage in the banking sector by exploring the mediational role of loyalty. International Journal of Bank Marketing, 34(3), 388-410.

Brige, A. (2006). Building relationship with customers by using technological solutions in commercial banks of Latvia. Baltic Journal of Management, 1(1), 24-33.

Brun, I., Durif, F., \& Ricard, L. (2014). E-relationship marketing: A cognitive mapping introspection in the banking sector. European Journal of Marketing, 48(3-4), 572594.

Chawla, D., \& Joshi, H. (2017). Consumer perspectives about mobile banking adoption in India - a cluster analysis. International Journal of Bank Marketing, 35(4), 616636.

Cvijović, J., Kostic-Stankovic, M., \& Janičić, R. (2014). Implementation of data bases in advertising, Marketing, 45 (4), 299-311, ISSN: 0354-3471.

Dahlstrom, R., Nygaard, A., Kimasheva, M., \& Ulvnes, A.M. (2014). How to recover trust in the banking industry?, A game theory approach to empirical analyses of bank and corporate customer relationships. International Journal of Bank Marketing, 32(4), 268-278.

Dimitriadis, S. (2011). Customers' relationship expectations and costs as segmentation variables: Preliminary evidence from banking. Journal of Services Marketing, 25(4), 294-308.

Ekinci, Y., Uray, N., \& Ülengin, F. (2014). A customer lifetime value model for the banking industry: A guide to marketing actions. European Journal of Marketing, 48(3-4), 761-784. 
Cvijović J. et al.: Customer relationship management in banking industry: Modern...

Estrella-Ramón, A. (2017). Explaining customers' financial service choice with loyalty and cross-buying behaviour. Journal of Services Marketing, 31(6), 539-555.

Estrella-Ramón, A., Sánchez-Pérez, M., Swinnen, G., \& VanHoof, K. (2017). A model to improve management of banking customers. Industrial Management \& Data Systems, 117(2), 250-266.

Heinonen, K. (2014). Multiple perspectives on customer relationships. International Journal of Bank Marketing, 32(6), 450-456.

Herington, C., \& Weaven, S. (2007). Can banks improve customer relationships with high quality online services?. Managing Service Quality, 17(4), 404-427.

Jugovic, T., Petrovic, D., \& Kostic-Stankovic, M. (2015). Customer relationship management as a source of competitiveness of companies in changing environment, Marketing, 46 (4), 285-296, ISSN: 0354-3471.

Kaabachi, S., Mrad, B.S., \& Petrescu, M. (2017). Consumer initial trust toward internetonly banks in France. International Journal of Bank Marketing, 35(6), 903924.

Kaushik, A.K., \& Rahman, Z. (2015). Innovation adoption across self-service banking technologies in India. International Journal of Bank Marketing, 33(2), 96-121.

Komazec, S., Todorovic, I., Kostic-Stankovic, M., \& Jaško, O. (2015). Introducing CRM Concept and Accompanying Organizational Change in Public Company as a Possibility for Improving Satisfaction of Residents. Economic and Social Development, 9th International Scientific Conference, Varaždin, Croatia, 469-478. ISBN: 978-953-6125-16-6.

Kostic-Stankovic, M. (2013). Marketing communications in customer relationship management, Andrejević Endowment, Belgrade, ISSN 1821-2484.

Larsson, A., \& Viitaoja, Y. (2017). Building customer loyalty in digital banking: A study of bank staff's perspectives on the challenges of digital CRM and loyalty. International Journal of Bank Marketing, 35(6), 858-877.

Lee, C.C., \& Liu, T.Y. (2017). Insurance development, banking activities, and regional output: Evidence from China. Empirical Economics, 53(3), 1059-1081.

Lewis, N.K., Palmer, A., \& Moll, A. (2010). Predicting young consumers' take up of mobile banking services. International Journal of Bank Marketing, 28, 410-432.

Liébana-Cabanillas, F., Muñoz-Leiva, F., \& Rejón-Guardia, F. (2013). The determinants of satisfaction with e-banking. Industrial Management \& Data Systems, 113(5), 750-767.

Lundahl, N., Vegholm, F., \& Silver, L. (2009). Technical and functional determinants of customer satisfaction in the bank-SME relationship. Managing Service Quality, 19(5), 581-594.

Lymperopoulos, C., Chaniotakis, I.E., \& Soureli, M. (2013). The role of price satisfaction in managing customer relationships: The case of financial services. Marketing Intelligence \& Planning, 31(3), 216-228.

Mishra, V., \& Vaithianathan, S. (2015). Customer personality and relationship satisfaction: Empirical evidence from Indian banking sector. International Journal of Bank Marketing, 33(2), 122-142.

Ndubisi, N.O., Wah, K.C., \& Ndubisi, G.C. (2007). Supplier-customer relationship management and customer loyalty. Journal of Enterprise Information Management, 20(2), 222-236.

Ofori, K.S., Boateng, O.A.F., \& Gvozdanovic, I. (2017). Examining customers' continuance intentions towards internet banking usage. Marketing Intelligence \& Planning, 35(6), 756-773.

Industrija, Vol.45, No.3, 2017 
Cvijović J. et al.: Customer relationship management in banking industry: Modern...

Padmavathy, C., Balaji, M.S., \& Sivakumar, V.J. (2012). Measuring effectiveness of customer relationship management in Indian retail banks. International Journal of Bank Marketing, 30(4), 246-266.

Paul, J., Mittal, A., \& Srivastav, G. (2016). Impact of service quality on customer satisfaction in private and public sector banks. International Journal of Bank Marketing, 34(5), 606-622.

Pedron, C.D., Picoto, W.N., Dhillon, G., \& Caldeira, M. (2016). Value-focused objectives for CRM system adoption. Industrial Management \& Data Systems, 116(3), 526-545.

Rezghi, A.R., Valmohammadi, C., \& Yousefpoor, J. (2014). The relationship between customer satisfaction and customer relationship management system: A case study of Ghavamin Bank. Industrial and Commercial Training, 46(4), 220-227.

Saarijärvi, H., Karjaluoto, H., \& Kuusela, H. (2013). Customer relationship management: The evolving role of customer data. Marketing Intelligence \& Planning, 31(6), 584-600.

Saberi, M., Hussain, O.K., \& Chang, E. (2017). Past, present and future of contact centers: A literature review. Business Process Management Journal, 23(3), 574597.

Shakil, M., Shahid, A., \& Ehtisham-Ul-Mujeeb, R. (2012). ECRM and customers: A case of Askari Commercial Bank, Pakistan. Business Strategy Series, 13(6), 323330.

Sampaio, C.H., Ladeira, W.J., \& Santini, F.D.O. (2017). Apps for mobile banking and customer satisfaction: A cross-cultural study. International Journal of Bank Marketing, 35(7), 1133-1153.

Sangle, P.S., \& Awasthi, P. (2011). Consumer's expectations from mobile CRM services: A banking context. Business Process Management Journal, 17(6), 898918.

Saxena, S., \& Al-Tamimi, T.A.S.M. (2017). Big data and Internet of Things (IoT) technologies in Omani banks: A case study. Foresight, 19(4), 409-420.

Strandberg, C., Wahlberg, O., \& Öhman, P. (2012). Challenges in serving the mass affluent segment: Bank customer perceptions of service quality. Managing Service Quality: An International Journal, 22(4), 359-385.

Stefanov, D., \& Kostić-Stanković, M. (2014). Organization of contact centers communication channels and employees in the contact center, Bankarstvo, 1/2015, 116-135.

Stefanov, D., Kostic-Stankovic, M., \& Makajic-Nikolic, D. (2015), Distribution of Operators in the Support Service of the Contact Center of Komercijalna Banka ad Belgrade. SYM-OP-IS 2014, Divcibare, Serbia, (355-360), ISBN:978-86-7395-3250 .

Tang, J., \& Ai, L. (2013). The system integration of anti-money laundering data reporting and customer relationship management in commercial banks. Journal of Money Laundering Control, 16(3), 231-237.

Tran, H.T.T., \& Corner, J. (2016). The impact of communication channels on mobile banking adoption. International Journal of Bank Marketing, 34(1), 78-109.

Valmohammadi, C., \& Beladpas, M. (2014). Customer relationship management and service quality, a survey within the banking sector. Industrial and Commercial Training, 46(2), 77-83.

Vegholm, F. (2011). Relationship marketing and the management of corporate image in the bank-SME relationship. Management Research Review, 34(3), 325-336. 
Cvijović J. et al.: Customer relationship management in banking industry: Modern...

Wisskirchen, C., Vater, D., Wright, T., de Backer, P., \& Detrick, C. (2006). The customer-led bank: Converting customers from defectors into fans. Strategy \& Leadership, 34(2), 10-20.

Zineldin, M. (2005). Quality and customer relationship management (CRM) as competitive strategy in the Swedish banking industry. The TQM Magazine, 17(4), 329-344. 